\title{
IDEIAS PEDAGÓGICAS E PRÁTICAS EDUCACIONAIS DIFUNDIDAS PELOS PRIMEIROS JESUÍTAS NAS AMÉRICAS
}

\author{
TEACHING IDEAS AND EDUCATIONAL PRACTICES DISSEMINATED BY THEEARLY \\ JESUITSIN THE AMERICAS \\ IDEAS PEDAGÓGICAS Y PRÁCTICAS EDUCACIONALES DIFUNDIDAS POR LOS PRIMEROS \\ JESUITAS EN LAS AMÉRICAS
}

(ช)

Zuley Jhojana Duran Peña

Doutoranda em Filosofia e História da Educação, Unicamp | Brasil

E-mail: zuleyjhojanaduran@gmail.com

Márcia Chaves Gamboa
Doutora em Educação pela Unicamp. Aposentada da UFAL. Pesquisadora visitante no Grupo Paideia da FE/Unicamp.
Pesquisadora principal do projeto Temático “Epistefnordeste”, financiado pela FAPESP | Brasil
E-mail: chavesgamboa@gmail.com

REVISTA PEDAGÓGICA

Revista do Programa de Pós-graduação em Educação da Unochapecó | ISSN 1984-1566

Universidade Comunitária da Região de Chapecó | Chapecó-SC, Brasil

Como referenciar este artigo: PEÑA, Z. J. D. CHAVES GAMBOA, M. Ideias pedagógicas e práticas educacionais difundidas pelos primeiros jesuítas nas américas. Revista Pedagógica, Chapecó, v.16, n.33, p. 169-186, Jul./Dez. 2014.

\begin{abstract}
RESUMO: Neste artigo, buscamos apresentar a ação educacional da Companhia de Jesus no conjunto da empreitada colonizadora mercantilista nas Américas. Tratando de entender a ação educacional e cultural dos Jesuítas sobre a matriz política da imposição mercantilista e sua face aculturadora, assim como, a cristianização forçada que justificava a ação exploradora. Também destacamos, como a Companhia de Jesus estabeleceu ações pedagógicas encaminhadas à educação de novas gerações e à atuação missionária de transmitir os valores religiosos. Os jesuítas, com o objetivo de evangelizar os ameríndios, mediaram não só em os valores religiosos, mas também, cunharam uma cultura diferente através de estratégias pedagógicas tais como: a música, a literatura e o teatro.
\end{abstract}

PALAVRAS-CHAVE: Teorias pedagógicas. Jesuítas. Educação Colonial. Colonialismos.
ABSTRACT: In this article, we seek to present the educational process of the Companyof Jesus throughout the mercantilist colonial enterprise in the Americas. Trying tounderst and theeducationaland cultural actions of the Jesuits on the political origins of mercantilist imposition and the process of acculturation, as well as,the forced Christianization that justifiedan exploratoryaction.We also highlight, asthe Society of Jesus established pedagogical actions directed to education of new generations of missionary and to the missionary activity of transmitting religious values. The Jesuits, with the goal of evangelizing Amerindians, mediated not only in religious values, also create a different culture through teaching strategies such as: music, literature and theater.

KEYWORDS: Pedagogical Theories. Jesuits. Colonial Education. Colonialism. 


\section{INTRODUÇÃO}

Este trabalho apresenta os resultados de pesquisa histórica relacionada às ideas pedagógicas e práticas educacionais difundidas e estabelecidas pelos jesuítas nas Américas. Foram recuperados e caracterizados os registros dos processos pedagógicos estabelecidos pelos missionários da companhia de Jesus, durante o período colonial, nas colônias portuguesas e espanholas. Para análise e caracterização das fontes utilizamos a metodologia da documentação histórica que contou com algumas fontes privilegiadas, tais como: documentos históricos, jornais e enciclopédias, localizados no Arquivo Histórico da Universidade Javeriana da Colômbia. Também foram consultados documentos no Arquivo Geral da Nação e no Instituto Colombiano de Antropologia e História- ICANH. Para compor a fundamentação e a contextualização histórica do estudo foi feita uma revisão dessa literatura. Com base nas teorias pedagógicas da América Latina, os dados são interpretados para caracterizar essa fase histórica. O estudo oferece uma caracterização e a análise dos processos educacionais desenvolvidos pelos jesuítas, assim como, a identificação das concepções de educação e de política educacional que orientaram essas experiências.

Este texto foi organizado na seguinte ordem: 1) a empresa colonizadora no século XVI: uma aurora malograda; 2) a ação educacional e cultural dos jesuítas nas Américas: imposições, descompassos e composições; 3) considerações interpretativas sobre a ação educacional da Companhia de Jesus; 4) o uso do teatro e da música como instrumento de evangelização.

\section{A EMPRESA COLONIZADORA NO SÉCULO XVI: UMA AURORA MALOGRADA}

A empresa colonizadora deve ser compreendida no contexto histórico da transformação no modo de produção feudal. Segundo Huberman (1986), o mercantilismo desenvolvido por Espanha e Portugal foi uma decorrência natural da necessidade de lucro que provocou a expansão ultramarina, pois seu espaço no continente ibérico já não dava mais condições de expansão. Foi assim como, tanto Portugal como Espanha navegaram atrás de colônias e de novas terras.

Neste contexto, mercadores que não se conformavam em ver como os lucros enormes vindos do comércio com Oriente ficavam unicamente baixo domínio dos italianos, principalmente da Veneza e Gênova e desejando participar dele, pois poderiam ganhar muito dinheiro com as mercadorias orientais, esforçaram-se por alcançar a abertura de uma nova rota que os levasse às Índias por um 
caminho que não fosse controlado pelos venezianos. Assim, navios se fizeram mar adentro, em todas as direções, uns ao norte ao mar Ártico, com a esperança de encontrar lá uma via alternativa, outros pelo sul, ao longo da costa da África. Finalmente, em 1497, Vasco de Gama, por essa rota do sul, circunavegou o continente africano, e, em 1498 ancorou no porto de Calecute, Índia. Descobrindo, assim, o tão ansiando caminho marítimo que os levaria as Índias.

\begin{abstract}
Modificou-se, então, a direção das correntes do comércio. Se anteriormente a posição geográfica de Veneza e das cidades do sul da Alemanha lhes proporcionava vantagens sobre os demais países situados mais a oeste, agora eram esses países da costa atlântica que contavam com mais vantagens Veneza e as cidades que a ela se ligavam comercialmente passam, então, a ficar fora da principal via de comercio. (Huberman, 1986, p. 90)
\end{abstract}

Portanto, o Atlântico se tornou a nova rota mais importante, para que Portugal, Espanha, Holanda, Inglaterra e França ascenderam à iminência comercial. Huberman (1986) assinala este período da história como uma 'Revolução Comercial', já que o comércio cresceu paulatinamente e passou a dar passos gigantescos. Não só no velho mundo da Europa e regiões da Ásia se abriram aos comerciantes empreendedores, mas também aos novos mundos da América e África, abrangendo quatro continentes e tendo rotas marítimas como estradas.

Uma vez realizadas as 'descobertas', fazia-se necessário erguer fortalezas, estabelecer guarnições de homens nos 'postos', efetuar acordos com os nativos, desenvolver o comércio, descobrir métodos de manter afastados os estranhos, isto para não falar dos preparativos longos e dispendiosos (como comprar ou construir um navio, engajar tripulação e fornecer alimentação e equipamento durante as jornadas incertas e perigosas). Tudo isto custava muito, sendo necessários grandes capitais, obtidos pela venda de ações a muitas pessoas que se poderia obter o capital necessário para financiar as grandes expedições comerciais, marítimas e colonizadoras.

As grandes casas bancárias alemãs e italianas da época (Fugger, Welser, Peruzzi, Medici, entre outras) emprestavam capital a mercadores, a reis e príncipes e, em troca, recebiam proventos de minas, de especulações comerciais, de terras da coroa, de praticamente todo tipo de empreendimento que desse lucro. Quando os empréstimos não eram repostos, tornavam-se donos de propriedades, minas, terras. O que tivesse sido dado como garantia. (Huberman, 1986, p. 94) 
Diante deste panorama, pode-se perceber que os governos, como parte do pagamento, concederam monopólios aos que arriscaram dinheiro nessas novas empresas. Também, podemos indicar que as novas indústrias desde o início foram organizadas em bases capitalistas e que a máquina financeira para enfrentar as necessidades do comércio em expansão foi posta em movimento no século XVI por monarcas, mercadores e banqueiros, os quais aumentaram suas fortunas, explorando as novas terras e aniquilando seus moradores. Vimos, portanto, que o motivo que impulsionaria os navios espanhóis, e portugueses, a arremeterem ao Atlântico não é outro senão a busca de ouro e prata, metais preciosos necessários para alavancar a riqueza mercantilista, os mercados de insumos e de consumo, a exploração das riquezas naturais e a afirmação do poder do rei e da realeza feudal.

\section{A AÇÃO EDUCACIONAL E CULTURAL DOS JESUÍTAS NAS AMÉRICAS: IMPOSIÇÕES, DESCOMPASSOS E COMPOSIÇÕES}

\section{A instalação das ordens religiosas}

Foi na época dos reis católicos, Isabel e Fernando, que se configurou a estrutura da cristandade das Índias, estendendo o padroado ${ }^{1}$ das Ilhas Canárias e Granada às novas terras dominadas. E é, no ano de 1493, com a chegada do primeiro grupo de missionários pertencentes à ordem Franciscana às terras descobertas que se dá começo à evangelização Latino-Americana.

Dussel (1992, p. 11) destaca que com a invasão de Hernan Cortês, ao império asteca, começa o processo de evangelização global. Passa-se, assim, do ciclo

1 Designação do conjunto de privilégios concedidos pela Santa Sé aos reis de Portugal e de Espanha. Tratava-se de um instrumento jurídico tipicamente medieval que possibilitava um domínio direto da Coroa nos negócios religiosos, especialmente nos aspectos administrativos, jurídicos e financeiros. Porém, os aspectos religiosos também eram afetados por tal domínio. Padres, religiosos e bispos eram também funcionários da Coroa. Isso implica, em grande parte, o fato de que religião e religiosidade eram assuntos de Estado (e vice-versa em muitos casos). A união indissociável entre a Igreja Católica e o Estado português e espanhol marcou a ação colonizadora desses dois reinos em disputa pela hegemonia no comércio mundial no início dos Tempos Modernos e também as ações pastorais de atrair à fé católica os povos nativos das terras conquistadas e, ainda, a luta contra o avanço do protestantismo. (Iglesias, 2010, p. 24) evangelizador do caribe, aos ciclos mexicanos, centroamericanos, incaico, e chibcha. Nestes lugares habitavam a maior parte da população americana pré-hispânica. Também, destaca que a evangelização orgânica na América começa quando em 14 de maio de 1524 chegam a San Juan de Uluas os 'doze apóstolos' franciscanos. Em 2 de julho de 1526, desembarcam 12 dominicanos; e, em 22 de maio de 1533, os agostinianos.

\section{Estabelecimento e processo evangelizador da Companhia de Jesus}

A Companhia de Jesus nasceu como uma tentativa de a Igreja Católica combater a Reforma Protestante Luterana (1483-1546). Esta fundação se originou na conjuntura da chamada contrareforma católica ${ }^{2}$. A educação também foi 
2 Foi um movimento liderado pelo Papa Paulo III, com o objetivo de frear o avanço da Reforma Protestante, e por sua vez reformar alguns princípios e comportamentos que não andavam bem dentro da própria Igreja. Animou e incentivou o clero a se dedicar com mais afinco da formação intelectual. Incentivou a formação de uma comissão para articular o procedimento da Reforma Católica. Este trabalho foi continuado pelos Papas que se seguiram. O Papa Paulo IV, considerado um reformador ativo. O Papa Pio V, publicou uma nova versão do catecismo da Igreja. (Silva, 2009, p. 44). modelada por esta contrarreforma; Silva destaca(2009, p. 44) a proposta das teses interpretativas sobre o movimento e o modelo educacional da ContraReforma Católica da Europa dos séculos XVI, proposto por Nunes (1986). Segundo o autor, dentro do processo entendido como 'Contrarreforma', ocupa lugar especial a criação e a atuação da Companhia de Jesus, na reorientação do império mercantil-salvacionista. A Companhia de Jesus desenvolvera um papel que ultrapassaria ao de mera congregação religiosa, visto que sua atuação histórica se tornaria a face nova da própria Igreja, questionada pelos movimentos reformadores e pela vertente leiga, moderna, politicamente hostil à ação da Igreja é marcada pelo forte acento anticlerical que surgia na Europa desta época. Assim, não se pode desligar uma coisa da outra: uma Europa em crise de transformações profunda, que coincide com as mudanças das relações econômicas, um mundo feudal em decadência e superação e, dentro dele, a Igreja que se vê questionada pela Reforma Luterana e outras reformas deixando claro que novas forças compõem a promessa de uma nova ordem social. Dentro desse mundo confuso, a Igreja surpreendida pela história, busca refazer, rearmarse e enfrentar as transformações históricas, jogando nelas a sua própria sobrevivência. A atuação dos Jesuítas tornou-se, então, uma das principais vertentes de toda uma empreitada da Igreja contra a embrionária entidade moderna e a vigorosa identidade protestante, aliadas às estratégias de reação, mecanismos e recursos históricos de que a Igreja lança mão para se manter num mundo que se transforma (Silva, 2009, p. 44).

Nesse contexto, os membros da Companhia de Jesus, com Inácio de Loyola como seu superior-geral, com muitos privilégios concedidos pelo papa, e com a função de serem 'soldados da Igreja' embarcam na missão de combater o avanço do protestantismo colocando em marcha diversas estratégias entre as quais destacamos: a criação de escolas religiosas, assim como a expansão do domínio católico aos demais continentes, sobretudo a conversão ao catolicismo dos povos dos continentes recém-descobertos.

Para efetivar a cristianização desta população instituise uma política de doutrinamento dos povos ameríndios, a qual consistia em organizar métodos de agrupamento, congregando os naturais em povoados. Os colonizadores achavam que a condição nômade dos naturais tornava impossível sua sujeição a uma vida 'política e humana', condições necessárias para sua conversão à fé e à vida cristã.

[...] Se constituirán poblaciones en que los indios puedan vivir y estén juntos, según como están las personas que viven en estos nuestros reinos, es decir, con morada y parcela de labradío que pueda sustentar la 
familia; (2) Casa apartada en que moren con su mujer y hijos (sic) [...] según y de la manera que tienen los vecinos de nuestros reinos; (3) Régimen municipal con regimiento y justicia que tutelarán especialmente la condición ciudadana del indígena, evitando su reducción a servidumbre. En concreto: que los cristianos que están en las dichas islas (no) se sirvan de los dichos indios (ni) sus mujeres, ni hijos ni hijas (sic) [...] ni consientan que se sirvan dellos (sic) como fasta aquí no han fecho, salvo queriendo los dichos indios por su propia voluntad e pagándoles los jornales que justo fuere, según que por el nuestro gobernador fuesen tasados; (4) Supresión gradual y discreta de costumbre indígenas contrarias a la práctica cristiana: la desnudez, procurando que se vistan e anden como hombres razonables; los baños rituales que a ellos façe (sic) mucho daño, y en general que los dichos indios non fagan (sic) las cosas que fasta aquí solían façer (sic); (5) una iglesia con su escuela adjunta en cada nueva población, en las que se realizarán la catequesis y la instrucción, a las que se señalara dotación adecuada a base de los diezmos eclesiásticos que por concesión pontifica disfrutaban ya los Reyes; (6) un clérigo en cada población constituida con funciones de cura y maestro, con su propia dotación decimal; (7) Un prelado o comisario apostólico con atribuciones episcopales, o, más indefinidamente, que tenga cargo de cumplir e procurar e façer (sic) que se faga (sic) todo lo que se debe façer (sic) en las cosas tocantes a lo espiritual en las dichas Indias, así por los clérigos como por los legos; (8) Una política matrimonial y racial que tienda a la amalgama de las dos poblaciones mediante los vínculos conyugales que inculcarán los clérigos de la colonia: los dicho capellanes procuren que los indios se casen con sus mujeres e que así mismo procuren que algunos cristianos se casen con algunas mujeres indias e las mujeres cristianas con algunos indios, porque los unos y los otros se comuniquen y se enseñen para ser adoctrinados en las cosas de nuestra Santa Fé Católica.(Iglesias, 2012, p. 23,24).

Diante destas normas, Iglesias (2010) especifica que desde o início o processo colonizador foi controlado. Os monarcas sabiam o que queriam e manifestaram prontamente sua vontade. Também, destaca que os missionários que vieram a estas terras sabiam as tarefa que lhes aguardavam. Respeito ao método empregado para tornar efetivo este processo, considera-se que foi criado e adaptado ao próprio ambiente colonial e apoiado em outras experiências evangelizadoras anteriores. 


\title{
CONSIDERAÇÕES INTERPRETATIVAS SOBRE A AÇÃO EDUCACIONAL DA COMPANHIA DE JESUS
}

No momento da chegada dos colonizadores as novas terras descobertas iniciaram um processo de remodelação das sociedades pré-existentes. Eles estabeleceram relações sociais e estruturas produtivas que lhes proporcionaram um ambiente de riqueza e de subsistência.

\begin{abstract}
Não se pode negar o caráter constante de coação e dependência estrita a que foram submetidos índios, negros e mestiços nas várias formas produtivas das Américas portuguesas e espanhola. Para extrair os seus bens com mais eficácia e segurança, o conquistador enrijou os mecanismos de exploração e de controle.(Bosi, 1992, p. 21)
\end{abstract}

Para manter os ameríndios sob seu domínio surgiram as 'doctrinas' ou paróquias de índios e as reducciones, assim, encontrou-se a maneira de aglomerar os nativos, controlá-los e cobrar os tributos, 'encomendár-los' e repartí-los. Desta maneira, o Estado colonial conseguiu o máximo que suas forças permitiam. Seu propósito era não perder o controle dos nativos em mãos dos conquistadores, assegurando assim os tributos e a reprodução do sistema produtivo.

Assim, as intenções dos colonizadores, a priori, eram a procura de novas riquezas e territórios para benefícios da coroa e dos patrocinadores da empresa conquistadora. Neste processo, os missionários exerceram um papel de 'facilitadores', já que em nome do cristianismo se legitimou uma prática e uma conduta que arrasaria os povos Ameríndios. Quando falamos de entes facilitadores, referimo-nos ao papel que desempenhou a Companhia de Jesus no campo da educação porque, desde ali, gestouse a incorporação da sociedade ameríndia à civilização ocidental mediante um processo de aculturação, isto é, a fixação de práticas, técnicas, símbolos e, até, o conjunto de valores éticos e religiosos inerentes aos colonizadores. "No caso da educação instaurada no âmbito do processo de colonização, trata-se, evidentemente, de aculturação, já que as tradições e costumes que se busca inculcar decorrem de um dinamismo externo, isto é, que vai do meio cultural do colonizador para a situação objeto de colonização". (Saviani, 2007, p. 27)

Durante os primeiros anos de contato entre colonizadores e ameríndios, como precisamente afirma Gonzalbo (2008, p. 19), apresentou-se com grande intensidade o processo de transmissão, assimilação, imposição e adaptação de padrões culturais. Os 
conquistadores acreditando que a implantação de suas instituições e costumes eram um direito que desfrutavam como consequência do domínio político. Ante este fato, Os povos ameríndios viram quebrantadas sua organização social e política, sua cosmovisão e seu cotidiano. Também os europeus deveram modificar seus rígidos esquemas para dar lugar à realidade das novas terras, com homens, religiões e concepções de mundo diferenciadas.

A expansão da cultura dominante foi ao mesmo tempo um projeto autoritário; os grados de integração e assimilação dos novos vassalos do império espanhol e português foram sumamente variáveis. Assim, a educação se converteu em instrumento insubstituível de coação pacífica em mãos dos conquistadores; por outra parte, para os ameríndios representou o veículo que lhes permitiu o acesso à compreensão da nova ordem. Por conveniência e por convicção, a conquista espiritual foi inseparável da militar, e a evangelização constitui, durante muitos anos, a forma generalizada de estabelecer a educação.

A Companhia de Jesus estabeleceu ações pedagógicas encaminhadas à educação de novas gerações e à atuação missionária de transmitir os valores religiosos. Os jesuítas, com o objetivo de evangelizar os ameríndios, mediaram não só os valores religiosos, mas cunharam uma cultura diferente através de estratégias pedagógicas tais como: a música, a literatura e o teatro.

No Brasil [...] A primeira fase da educação jesuítica foi marcada pelo plano de instrução elaborado por Nóbrega. O plano iniciava-se com o aprendizado do português (para os índios); prosseguia com a doutrina cristã, a escola deler e escrever e, opcionalmente, canto orfeônico e musica instrumental; e culminava, de um lado, com o aprendizado profissional e agrícola e, de outro lado, com a gramática latina para aqueles que se destinavam a realizar estudos na Europa. [...] Sua aplicação foi precária, tendo cedo encontrado oposição no interior da própria Ordem Jesuítica, sendo finalmente suplantada pelo plano geral de estudos organizado pela Companhia de Jesus e consubstanciado no RatioStudiorum. (Saviani, 2007, p. 43)

Entre os escritos históricos dos jesuítas existem diversos relatos referentes aos métodos utilizados por estes para a evangelização da população ameríndia, além das referências acerca da instituição de 'escolas para índios', com frequência em seus textos e manuscritos se faz menção à seguinte expressão: "Procuren los nuestros que haya, en las doctrinas que tomaren, maestros de escuela que enseñe a los hijos de los indios más capaces a leer y escribir y a cantar y tañer diversos instrumentos" (Pacheco, 1959, p. 309). 
Além de ensinar as crianças a ler e a escrever, foi sugerido que se lhes ensinassem a cantar e a tocar um instrumento musical. Todas estas estratégias atrairiam a atenção das crianças para o aprendizado da doutrina cristã. Nesse sentido, a música, além de ser utilizada como recurso pedagógico, funcionou como método de aproximação e persuasão e como conteúdo cultural de ensino. A importância desta prática e sua funcionalidade dentro dos grupos, fez com que desde os primeiros contatos os missionários perseveram seu potencial enquanto metodologia evangelizadora. Também a música foi utilizada como método para memorizar a doutrina e como forma de socialização. (Iglesias, 2012, p. 77, 81)

A educação encaminhada às crianças se justificou, segundo (Iglesias, 2012, p. 69), "em razão da maior eficácia em relação à absorção de costumes. O potencial de maleabilidade infantil, somado á concepção empirista, simbolizada pela metáfora 'cera branda' - entre os espanhóis, que dominava o pensamento pedagógico naquele tempo, foi o que definiu a prática”.

\section{O USO DO TEATRO E DA MÚSICA COMO INSTRUMENTO DE EVANGELIZAÇÃO}

A pesar de que as representações teatrais estavam sendo censuradas nos centros educativos por parte do parlamento, os jesuítas não deixaram de utilizá-las como um instrumento educativo. O teatro escolar foi regulamentado severamente, mas introduzido no RatioStudiorum. Além de ser uma atividade recreativa, ajudava a fortalecer nos estudantes a memória, a educar a voz, a aumentar a confiança e o domínio de si, ademais de estas vantagens os padres o apontavam à formação cívica, moral e religiosa da juventude.

Com respeito ao uso do teatro no contexto evangelizador, Iglesias (2012, p. 84, 87) sugere que esta prática alcançou um caráter de Método. Sendo um importante modo de persuasão, tanto para a evangelização, como para a catequese mais abrangente. Esta afirmação a fundamenta no fato de além de esta prática ser um apreciado atrativo, lograva atingir um grande número de pessoas, tanto ameríndios, como espanhóis, de todas as idades. Destaca que, devido ao número reduzido de missionários em relação à quantidade de habitantes, o teatro ofereceu a vantagem de poder atingir a muitos ao mesmo tempo. Também assinala que o teatro não era uma atividade executada de forma espontânea. Porém, não se deve negar o caráter circunstancial do método, devido à dificuldade de expressão e ás barreiras linguísticas, encontradas pelos missionários, Esses foram, sem dúvida, os motivos para a instauração do teatro evangelizador, porém circunstancial não significa aleatório. 
3 Ao desembarcar em diferentes portos onde havia presença portuguesa, os jesuítas se depararam com práticas religiosas hindus, islâmicas, cristãs, budistas e até mesmo judaicas. Este era o contexto vivido por missionários católicos no oriente.
Também, Iglesias (2012, p. 86) discorda sobre as considerações de alguns críticos que julgam esta prática como sincretista e reflete afirmando que este trabalho pedagógico não deve ser considerado como 'prática sincretista', pois os conteúdos de todas as ações metodológicas- como são: o canto, a dança e teatro, levadas a cabo na América foram eminentemente cristãs e com fins planejadamente determinados pelas necessidades nascidas no processo de cristianização.

[...] o sincretismo carrega em seu conceito a própria negação da acusação, na medida em que exige a fusão de conceitos religiosos ou a influência de uma religião sobre outra. Isso, por si, já nega a tese do sincretismo, porque na América Colonial, não havia uma concepção de religião, e, muito menos, uma religião com a qual o Cristianismo pudesse se fundir. O que havia era um comportamento religioso, que, percebido pelos religiosos, foi aproveitado para a cristianização. (Iglesias, 2012, p. 86)

Assim, estas adaptações longe de serem práticas do sincretismo, foram métodos de aproximação, tanto da cultura, como do comportamento religioso, as quais permitiram a abertura para o assentamento de um sistema de ideias necessárias à consecução de um fim determinado.

\section{Música nas missões jesuítas pelo mundo e sua especificidade na América espanhola e portuguesa}

Antes e depois da morte de Ignácio de Loyola documentos revelam o estabelecimento de algumas práticas musicais pelos missioneiros ao redor do mundo. A missão jesuíta era apostólica, entre diversos povos e culturas, e cada realidade exigia adaptações. As experiências locais fizeram com que fossem revisadas algumas regras, o que acabo registrado em correspondências trocadas entre Europa, Ásia e América (Wittmann, 2011, p. 47).

\section{Estabelecimento do uso pedagógico da música nas missões jesuítas na India ${ }^{3}$}

Desde o estabelecimento das missões na Índia, podemos encontrar documentos donde se evidencia o surgimento da preocupação com respeito ao uso da música nas missões a cargo da Companhia de Jesus e o cuidado que se deveria tomar para não contrariar as constituições. 
Em 1543 os jesuítas portugueses chegaram à índia e antes mesmo da chegada do padre Nóbrega ao Brasil já eram cientes da utilidade que a música poderia ter no processo de conversão dos gentios. Em uma carta de 1545, o padre Antônio Criminalis expressou para Ignácio de Loyola a preocupação com o fato de os meninos cantarem nos ofícios.

[...] Apesar de ser do agrado dos locais [...] Eu gostaria que os meninos não cantassem coisa alguma, mas dizem que isso escandalizaria o povo, porque já tem este costume e que isso parece agradar muito ao senhor Deus. Meus companheiros dizem que aprenderam a cantar, mas eu lhes digo que não lhes prometam tal coisa, porque vai um pouco ao além do meu sentir, e me parece que não devemos cantar( Holler, 2010, p. 156).

Outros documentos nos revelam a importância que começou a ganhar a prática musical nas missões jesuíticas na Índia e a necessidade de se propor consensos que prometessem seu uso. Em uma carta do ano de 1556, o padre João de Polanco propõe tolerar o canto na Índia já que ele atrai o gentio.

[...] Propôs-se que se tolerasse o canto nos ofícios divinos nas regiões da índia, para que desse modo aqueles homens incultos fossem mais atraídos na religião ao culto de Deus. E isto, podia acontecer em Goa muito facilmente, onde os meninos cantavam nos ofícios, [...] e isso foi comprovado pelo padre Francisco Xavier; nem era difícil ensinar os cantores, uma vez que os meninos mais adiantados no canto ensinavam os demais (Holler, 2010, P. 157).

Aqui podemos apreciar uns dos primeiros documentos donde se solicita a aprovação ao uso da música em missões, cujo escrito pertence ao ano de 1558, nas instruções do padre Polanco às missões da Índia. Nela expressa

[...] Deve-se permitir o canto na índia e em outros lugares distantes, mesmo que isso não seja permitido à Companhia na Europa, se nesses locais isso for um auxilio para o culto de Deus e para o proveito espiritual, como se observas em Goa e na Etiópia (Holler, 2010, p. 157).

Podemos deduzir dos documentos acima expostos que, desde o início das missões Jesuítas, a utilização da música como instrumento pedagógico e cultural se fez 
4 Os visitadores eram os responsáveis pela organização dos trabalhos de evangelização, tornando-se os olhos e os ouvidos em áreas distantes do padre geral (Wittmann, 2011, p. 49). imprescindível no processo de conversão ao cristianismo, embora, Ignácio de Loyola e muitos de seus discípulos foram contra sua prática; estes terminaram aceitando e modificando as normas que vetavam seu uso.

\section{Uso pedagógico da música nas missões jesuítas no Brasil}

Diversos documentos históricos referentes à ação evangelizadora da Companhia de Jesus nas aldeias do Brasil nos demonstram que a prática musical pelos jesuítas foi mediada por diversas discussões seja em pró ou contra seu uso. Este fato foi registrado num manuscrito que se encontra conservado no arquivo dos jesuítas em Roma. Nele se encontra uma decisão acerca do uso da música nestas terras, este documento foi emitido pelo visitador ${ }^{4}$ Inácio de Azevedo e nele manifestava:

[...] Que os jesuítas não poderiam ensinar música nas suas escolas, assim como não deveriam cantar em missas ou procissões. [...] A vocação inaciana era apostólica, e deveria estar centrada em atividades como confissão e pregação. Deste modo os jesuítas estariam respeitando as regras das suas Constituições. (Wittmann, 2011, p. 51, grifos da autora).

Não entanto, o visitador Azevedo estipula que nos lugares donde só se - encontrem jesuítas se poderá fazer uso da música com algumas exceções. Desta maneira, davase licença para utilizar a música nas missões jesuíticas na América portuguesa.

[...] Nas partes onde não ha outros sacerdotes, como é Paratininga ou em aldeias entre os índios, (sic) ali poderão fazer, segundo vir o provincial que convém para edificação do povo, mais de maneira que não faltem por isso nos ministérios já ditos (Wittmann, 2011, p. 50).

O visitador Cristóvão de Gouveia também se manifestou e posicionou diante das manifestações musicais que viu e ouviu nestas terras. Isso pode ser conferido no siguiente documento

[...] Aviendomoços (sic) de escuela los ensenaran por espacio de hora, y media, assi(sic) a la mañana como a la tarde, a leer, y escrevir (sic), y depues de esso (sic) cantar a los que pareciere que tienen habilidad para eso aviendo (sic) quien lo sepa hazer (sic), 
mas no los castigue por su mano. Quitense (sic) las malas costumbres (sic) de los indios [...] y las buenas se conserven (Wittmann, 2011, p. 54).

Outros documentos destacam as posturas dos visitadores Azevedo e Gouveia e as concessões a favor da prática Musical feitas pelos padres gerais da ordem Aquaviva e Mercuriano.

[...] O que mais impressiona nos casos de Azevedo e Gouveia, é que praticas musicais incomuns foram defendidas por visitadores, mesmo quando transgrediam as constituições jesuíticas. Afinal, eram eles os representantes que agiam com propósito de ajustar as regulas do centro à periferia. De fato, ordenavam de acordo com a província visitada, no caso do Brasil, onde missionários, defendiam o uso da música por entenderem que era importante para o sucesso do trabalho de evangelização. Sabemos, também, da ordem de Polanco que havia flexibilizado as restrições musicais da Companhia a os padres em missões longínquas (Wittmann, 2011, p. 56).

Outros importantes exemplos acerca da utilização da música na ação missionária jesuítica no Brasil, assim como o grande valor desta prática não só como recurso pedagógico, mas também como método de aproximação e persuasão e como conteúdo cultural de ensino, são apresentados por Iglesias (2012) em sua pesquisa.

No primeiro exemplo podemos apreciar como desde a chegada dos primeiros jesuítas ao Brasil estes perceberam o potencial da prática musical enquanto metodologia evangelizadora. Isso poder ser comprovado no seguinte relato histórico.

Estes Gentios, que em extremo são afeiçoados à música e cantares, e em tanto que os feiticeiros que entre eles chamam santos, usam desta manha quando lhes querem apanhar alguma cousa. (Iglesias, 2012, p. 77).

Outra importante testemunha sobre o valor pedagógico da música na ação missionária jesuítica, foi pronunciado per Serafim Leite. Ao referir-se a esta prática entre os jesuítas dos primeiros tempos, no Brasil escreve:

Os gentios, em extremos são afeiçoados à música e cantares, observaram os padres, e os pajes bem sabiam antes dos Portugueses e dos Jesuítas. Mas logo os 
Jesuítas e os Portugueses aproveitaram essa inclinação(Iglesias, 2012, p. 78).

Como podemos observar existem abundantes registros que nos demonstram a institucionalização da prática musical em diversas missões a cargo da companhia de Jesus, como parte do processo educativo implementado pelos missionários no período colonial com o propósito evangelizador, de atração e persuasão das populações ameríndias.

\section{Utilização da música como elemento aculturador nas missões jesuíticas na América espanhola}

A Companhia de Jesus iniciou sua atuação na América Espanhola mais de meio século depois da América Portuguesa. Quando começaram seu labor missionário nestas terras já se tinham estabelecido e consolidado as normas que orientariam o ensino nas instituições educativas administradas pela ordem, ou seja, o RatioStudiorum. Neste território, os Jesuítas estabeleceram 'doutrinas e reduções de índios', nas quais, de acordo com as instruções enviadas pelo geral da ordem, Claudio Aquaviva, deveriam fundar escolas donde se ensinariam os filhos dos 'índios' a ler, a escrever, a cantar e a tocar um instrumento musical.

[...] Procuren los nuestros que haya, en las doctrinas que tomaren, maestros de escuela que enseñe a los hijos de los indios más capaces a leer y escribir y a cantar y tañer diversos instrumentos que sirven al oficio de la misa, todo lo cual enseñaran otros indios prácticos, como lo han hecho en el Perú, Méjico, y Filipinas (Pacheco, 1959, p. 309).

No documento, Aquaviva destaca que este modo de trabalhar com os 'povos deíndios' também estava sendo feito no Peru, México e as Filipinas. E pelos documentos acima expostos podemos afirmar que esta estratégia também foi posta em prática nas missões da Índia e do Brasil.

Embora o RatioStudiorum transmitirá claramente os preceitos pedagógicos da Companhia, como caminho alternativo para, primeiro incluir aos nativos dentro do contexto ocidental, ou seja, 'civilizá-los', os jesuítas utilizaram as práticas musicais para estabelecer um canal de comunicação por onde finalmente se consumasse o processo de aculturação.

Primeiro, mediante a convivência com os ameríndios, os jesuítas caracterizaram suas costumes, os ritos, os mitos, 
as crenças, a convivência social, a língua, entre outros; donde encontraram uma simbiose perfeita com a dança e a música, além de grande habilidade e gosto dos ameríndios por instrumentos musicais, que eles executavam. Desse modo, depois de fazer esta avaliação, foi planejada aquela intervenção cultural.

[...] A utilização da música gerou em áreas de missão celebrações católicas singulares, com características locais. Determinou também flexibilizações nas regras estabelecidas por Ignácio de Loyola. E isso não era estranho ao modo de proceder jesuítico, que previa uma liberdade de ação delimitada pela identidade que unia os membros da ordem. Essa adaptabilidade jesuítica, portanto, se caracterizou também no campo musical (Wittmann, 2011, p. 59).

Estes elementos apresentados nos ajudam a compreender como a música se foi incorporando nas missões a cargo da Companhia de Jesus, em diversos lugares, contextos e tempos e como se foi tornando um elemento indispensável no processo de conversão ao cristianismo. "A música era parte constituinte dos rituais religiosos, fossem as cerimônias indígenas, católicas ou já misturadas pelo contato. "A música torna-se canal essencial de tradução cultural e religiosa entre jesuítas e ameríndios"(Wittmann, 2011, p. 153).

[...] O processo de colonização abarca, de forma articulada, mas não homogênea, ou harmônica, antes dialeticamente, esses três momentos representados pela colonização propriamente dita, ou seja, a posse e exploração da terra subjugando o seus habitantes (os íncolas); a educação enquanto aculturação, isto é, a inculcação nos colonizados das praticas, técnicas, símbolos e valores próprios dos colonizadores; e a catequeses entendida como a difusão e conversão dos colonizados à religião dos colonizadores (Saviani, 2007, p. 29).

Segundo Iglesias (2012, p. 65), toda a ação evangelizadora na América teve caráter educativo e é impossível a divisão entre evangelização e educação no período colonial. Com relação a algumas das características da metodologia educativa dos jesuítas, a autora nos indica que os métodos de ensino utilizados para a catequese e para a alfabetização pelos missionários foram o ideográfico, e o fonético. O ideográfico consistia em apresentar a letra, representando-a por figuras semelhantes. Exemplo: À letra 'c' adicionava-se a figura de uma ferradura como representação. $\mathrm{O}$ fonético consistiu em relacionar cada letra 
do alfabeto a objetos e animais conhecidos, cujos nomes se iniciavam com tal letra. Quanto à escrita, os missionários mesclavam hierógrafos e figuras, correspondendo-os a frases inteiras escritas com caracteres europeus.

[...] O eixo do trabalho catequético era de caráter pedagógico, uma vez que os jesuítas consideravam que a primeira alternativa de conversão era o convencimento que implicava praticas pedagógicas institucionais (as escolas) e não institucionais (o exemplo). As primeiras eram mais visíveis. Entretanto, as formas não institucionalizadas do saber foram muito mais eficazes, onipresentes, radicais, em sua enganadora múltipla pequenez do que o que se passava nos Colégios, pelo menos do ponto de vista de instalação de uma dominação cultural (Saviani, 2007, p. 31).

Segundo Gonzalbo (2008, p. 20), a educação para os ameríndios apresentou características especiais que evoluíram segundo as exigências e necessidades dos dominadores. As metas educativas propostas pelas diversas autoridades pretendiam a integração dos novos vassalos. Assim, evangelização, castelhanização, incorporação à vida urbana e treinamento para o trabalho, formaram o conjunto de conhecimento e habilidades recomendados.

\section{CONCLUSÕES}

Concluímos este texto, apresentando um confronto entre a expansão mercantilista europeia, cujo objetivo era o de buscar novos mercados, mercadorias, como também, espaços para a expansão de seu regime, modelo econômico e sua cultura, e a própria cultura ameríndia situada num outro estágio de civilização e desenvolvimento. Enquanto os europeus eram povos bélicos, organizados em cidades, com conceitos de propriedade privada, hierarquia, com uma religião organizada sobre estruturas de poder e liturgias, em contraste, os ameríndios eram uma sociedade predominantemente nômade, clânica, com povos unidos através de uma tradição cultural comum, animista, fetichista com diversas expressões muito próprias tais como: danças e músicas, dentre outras. O encontro entre essas duas humanidades não foi um encontro amistoso, foi um encontro violento e a humanidade europeia, através da superioridade bélica e militar, terminou impondo sua cultura sobre a humanidade ameríndia.

Este processo de aculturação foi certamente determinado pela ação das ordenes religiosas que embarcaram para a América. Especificamente, a Companhia 
de Jesus estabeleceu diversas ações pedagógicas que propiciaram e justificaram o estabelecimento da nova ordem. Eles agiram de acordo com seu maior objetivo: a conversão dos nativos. Assim sendo, em seus escritos relataram costumes ameríndias pensando em estratégias de catequização, ou seja, em como civilizá-los para, por fim, torná-los cristãos. Nesse sentido, a música, a literatura e o teatro foram utilizadas como estratégias de conversão ao cristianismo a utilização destas práticas foi parte importantíssima da educação institucionalizada e implementada pelos missionários, assim como tornouse um dos principais métodos utilizados nas relações de ensino aprendizagem para a educação na América.

Também, a utilização de crianças na prática evangelizadora e musical foi outro método que ajudou no desenvolvimento da prática educacional colonial. Assim, este e outros métodos utilizados pelos missionários formaram os fundamentos por meio dos quais se desenvolveu a educação enquanto atividade mediada pelo trabalho pedagógico, ou educação sistematizada na América colonial.

\section{REFÊRENCIAS}

BOSI, Alfredo. Dialética da Colonização. 4 ed. São Paulo, Brasil: Companhia das Letras, 1992.

DUSSEL, Enrique. Historia liberationis : 500 anos de história da Igreja na América Latina. São Paulo, Brasil: Edições Paulinas, 1992.

HOLLER, Marcos. Os Jesuítas e a música no Brasil colonial. Campinas, SP: Editora Unicamp, 2010.

HUBERMAN, Leo. História da riqueza do homem. 21. eded. [S.l.] Rio de Janeiro, RJ: Livros Técnicos e Científicos, 1986.

IGLESIAS, Tania Conceição. A experiência educativa da Ordem Franciscana: aplicação na América e sua influência no Brasil Colonial. [Tese de Doutorado] Campinas, SP: FE-UNICAMP,2010.

Análise Comparada dos Métodos Franciscanos e Jesuíticos no Contexto Colonial. Campinas, SP: [Informe Pós-doutorado] Campinas, SP: FE-UNICAMP,2012.

PACHECO, Juan Manoel, S. J. Los Jesuitas em Colombia. Bogotá, Colombia: San Juan, 1959.

SAVIANI, Dermeval. História das ideias pedagógicas no Brasil. Campinas, SP: Autores Associados, 2007. 
186 IDEIAS PEDAGÓGICAS E PRÁTICAS EDUCACIONAIS DIFUNDIDAS PELOS PRIMEIROS JESUÍTAS NAS AMÉRICAS.

SILVA, José Carlos da. O ensino de filosofia na formação do agente religioso no Brasil colônia: uma identidade politica entre a vassalagem epistemológica tradicional e a experimentação pedagógica heroica (1549-1599). [Tese de Doutorado] Campinas, SP: FE-UNICAMP,2009.

WITTMANN, Luisa Tombini. Flautas e Maracás: música nas aldeias jesuíticas da América Portuguesa (séculos XVI e XVII). [Tese de Doutorado]. Instituto de Filosofia e Ciências Humanas. Campinas, SP: IFICH-UNICAMP, 2011. 